\title{
Free Radical Scavenging Activity of Juice and Ethanol Extracts of Garcinia Mangostana L. Leaves
}

\author{
Diniatik \\ Elza Sundhani
Faculty of Pharmacy, Universitas Muhammadiyah Purwokerto \\ Faculty of Pharmacy, Universitas Muhammadiyah Purwokerto \\ diniatik@yahoo.com.au
}

Nervita

Faculty of Pharmacy, Universitas Muhammadiyah Purwokerto

\begin{abstract}
The present research was conducted to assess the free radical scavenging activity of Garcinia mangostana $L$ leaves by DPPH $(1,1$, diphenyl-2 picryl hydrazyl) method. Free radical scavenging activity of juice and ethanolic extract of $G$. mangostana leaves were determined by using spectrophotometry UV-Vis method. Juice and $96 \%$ ethanol's extract was concentrated by using rotary evaporator to get thick extract produces rendement about $2.571 \%$ and 4.842 $\%$. IC 50 values for juice and ethanol extract was $19.372 \mu \mathrm{g} / \mathrm{ml}$ and $1.965 \mu \mathrm{g} / \mathrm{ml}$, it means at that concentration inhibited $50 \%$ of free radical DPPH scavenge. $\mathrm{IC}_{50}$ of $\mathrm{d}$ - $\alpha$-tocopherol was $0.737 \mu \mathrm{g} / \mathrm{ml}$. The result showed that juice are amounted ten times less than ethanol extract. When compared with d- $\alpha$ tocopherol as positive control, free radical scavenging activity of juice and ethanolic extract were twenty six and three times less than $d$ - $\alpha$-tocopherol. Based on the result of anova test with significant degree $95 \%$ can be concluded that free radical scavenging activity between juice and ethanol extract were different with d- $\alpha$-tocopherol.
\end{abstract}

Keywords: Garcinia mangostana L, free radical, DPPH, d- $\alpha$-tocopherol, juice.

\section{INTRODUCTION}

Free radicals are produced continually in various metabolic processes and exist in biological systems. They are important for maintaining normal physiological function. Reactive oxygen species (ROS) (e. g. superoxide anion, hydroxyl radical, and hydrogen peroxide) increases the possibility of a wide range of common degenerative diseases. Since plants or herbs contain a diverse range of bioactive molecules, many of which have antioxidant properties. Their extracts have been revealed the high antioxidant activity [1]. There has been a worldwide trend towards the use of natural phytochemicals present in fruits, vegetables, oil seeds, teas, herbs, berry crops and beans. Natural antioxidants have a wide range of biochemical activities, including inhibition of ROS generation, direct or indirect scavenging of free radicals and alteration of intracellular redox potential [2]. Mangosteen (G. mangostana) is one of the main commodities of Indonesian export, known as the Queen of Tropical Fruits. Even though the fruit has been exported, the avaibility of good quality fruit is still inadequate [3]. Most of Mangosteen metabolites are xanthones [4]. Xanthones have been isolated from part of this plant. Obolsky et al. [5] reported the leaves of this plant has 1, 5, 8-Trihydroxy-3- methoxy-2-(3-methylbut2-enyl) xanthone. Several studies have shown that xanthones obtained from mangosteen-fruit have remarkable biological activities and fifty xanthones have been isolated from pericarp of mangosteen fruit [6]. Mangosteen fruit juice has antioxidants activity with free radical scavenging activity found that the $\mathrm{IC}_{50}$ values for $\mathrm{ABTS}$ and DPPH were $0.23 \pm 0.46$ and $1.91 \pm 0.65$ $\mathrm{mg} / \mathrm{ml}$ [7].

There were many report of biological activity of $G$. mangostana. Several studies have shown that obtained xanthones from mangosteen have remarkable biological activities such as antioxidant, antitumoral, antiinflammatory, antiallergy, antibacterial, antifungal, and antiviral activities [8]. The twig extract of G. mangostana was the most effective sample against platelet aggregation caused by arachidonic acid [9] and several studies have been designed to examine the anticancer activities, hepatocellular carcinoma human leukemia of xanthones from mangosteen-fruit pericarp [6]. Antioxidant activity of ethanolic extract G. mangostana leaves and skin bark 6.749 ppm dan 5.658 ppm with DPPH as free redical [10]. From this research can conclude that free radical scavenging activity from leaves and skin bark extract of $G$. mangostana is not significantly different, if we get substance from skin bark of $G$. mangostana can damage this plant but if we get from leaf is doesn't. The aim from this research is to examined free radical scavenging activity of juice and ethanolic extract of $G$. mangostana leaves with $\mathrm{d}-\alpha-$ tocoferol as standards. 


\section{METHOD}

Plant materials. The plants were collected from Sokaraja District, Banyumas Regency, Central Java Province, Indonesia on March 2012 and identified in laboratory of Botany and genetic Faculty of FKIP, Muhammadiyah University of Purwokerto, Indonesia. The voucher specimen was kept in Laboratory of Pharmaceutical Biology, Muhammadiyah University of Purwokerto, Indonesia.

Preparation of juice. Leaves of G. mangostana (3 $\mathrm{kg}$ ) is added with 3 liters of water at blender, after the blend was pressed with flannel cloth and was concentrated by using rotary evaporator and waterbath during five days with temperature less than $40^{\circ} \mathrm{C}$ to get thick extract produces.

Preparation ethanol extract. G. mangostana leaves were collected, dried and pulverized by using mechanical grinder. 500 grams of powder were extracted by maseration method with solvent water:ethanol 96\% (1:5) during 24 hours and re-maseration with solvent water:ethanol 96\% (1:4). After extracting the exhaustive extraction, ethanol extract was collected and concentrated under reduced pressure at $40^{\circ} \mathrm{C}$ by using rotary evaporator.

Free radical scavenging activity evaluation. Juice with concentration $8 ; 4 ; 2$; and $1 \mu \mathrm{g} / \mathrm{ml}$, were evaluated for its free radical scavenging activity using DPPH (diphenylpicrylhidrazyl) method, as well as Ethanol extract in serial concentration of $1 ; 2 ; 4$; and $8 \mu \mathrm{g} / \mathrm{ml}$. Ability to transfer electron from juice and ethanol extract were measured by its transformation from purple color to yellow color of DPPH solution in methanol observed by using UV-Vis Spectrophotometer.

There were $50 \mu \mathrm{l}$ of juice and ethanol extract diluted on methanol and was added $0.002 \%$ DPPH solution in methanol $10 \mathrm{ml}$. After incubated at room temperature for 30 minutes, absorbance was measured at $515.6 \mathrm{~nm}$ using a blank solution. Free radical inhibition of DPPH in percent $(\%)$ was calculated using this formula:

$\mathbf{I}(\%)=($ AbSblank $-\mathbf{A b s}$ sample/ $/$ Absblank $) \times 100$

Where Absblank (absorbance of blank) was absorbance of control reaction (contain all reagents without sample). Concentration where juice and ethanolic extract showing 50\% inhibition $\left(\mathrm{IC}_{50}\right)$ were calculated from linear regression equation from curve of percent inhibition vs. sample concentration. Antioxidant synthetics, $\mathrm{d}$ - $\alpha$-tocopherol were used as positive control.

\section{RESULT}

This research was designed to assess the free radicals scavenging activity from juice and ethanol extract of mangosteen leaves compared with $\mathrm{d}$ - $\alpha$-tocopherol as standard. Extract of juice from mangosteen leaves were extracted by blending fresh leaves of mangosteen then pressing the blend with flannel cloth. The filtrate was concentrated by using rotary evaporator to get thick extract. Ethanol extract were obtained from fresh leaves of mangosteen. The leaves was washed with running water to remove any dirt or contaminants such as soil, or other materials on the leaves. Selected leaves $(2 \mathrm{~kg})$ were good for the next steps being aerated and dried in the sun covered with black cloth. During heating, the material is not organized piles and turned upside - behind that uniform heating and rapid drying. Drying is carried out until the moisture content is less than $10 \%$ or until the leaves and bark is easy to be destroyed when crushed. The purpose of drying is to prevent the growth of fungi or microorganisms and the decomposition of active compounds by enzymatic reaction and the hydrolysis process because of its high water content, so that crude produced is not easily damaged so it can be kept in a relatively long time. Obtained further dried simplicia was blended with blender to minimize the surface area so that the contact surface of the particles with solvent bigger bulbs and extraction becomes more optimal.

The method implemented is maceration. This method is the simplest method because it is easy to do, inexpensive, does not require sophisticated equipment. Maceration is done by soaking the powder in the liquid botanicals solvent. In this research, to improve the effectiveness of the extraction, stirring and re-maceration is conducted, macerated for 24 hours with a comparison between simplicia with $96 \%$ ethanol is 1:5, and 1:4 for re-maceration. The trick is as much as 500 grams of powder botanicals macerated with ethanol $96 \%$ as much as 2.5 liters, then pressed with flannel cloth. Obtained pulp was macerated again with $96 \%$ ethanol as much as 1.25 liters.

Extracts derived either from the juice and extract was evaporated with a rotary evaporator and over a water bath until having thick consistency. Evaporation is conducted to eliminate solvent solution so as not to affect the free radical scavenging activity assay following condensed extract obtained as shown in Table 1 .

Table 1: Rendement juice and extract Mangosteen leaves

\begin{tabular}{llllll}
\hline & \multicolumn{3}{c}{ Juice } & \multicolumn{3}{c}{ Ethanolic extract } \\
$\begin{array}{l}\text { Fresh } \\
\text { Leaves } \\
(\mathrm{g})\end{array}$ & $\begin{array}{l}\text { Thick } \\
\text { extract } \\
(\mathrm{g})\end{array}$ & $\begin{array}{l}\text { Rendement } \\
(\% \mathrm{w} / \mathrm{w})\end{array}$ & $\begin{array}{l}\text { Simplisia } \\
(\mathrm{g})\end{array}$ & $\begin{array}{l}\text { thick } \\
\text { extract } \\
(\mathrm{g})\end{array}$ & $\begin{array}{l}\text { Rendement } \\
(\% \mathrm{w} / \mathrm{w})\end{array}$ \\
\hline 3000 & 77.14 & 2.571 & $\begin{array}{l}500 \\
\text { (from } \\
\text { kg } \\
\text { leaves })\end{array}$ \\
\hline
\end{tabular}

Tests conducted on the free radical scavenging activity from juice and ethanolic extracts of G. mangostana leaves and $d$ - $\alpha$-tocopherol as positive control. Free radical scavenging activity was determined using DPPH (1,1-diphenyl-2-pikril hidrazil), a stable synthetic radical in aqueous solution or methanol and able to accept an electron or hydrogen radical to become a stable diamagnetic molecule. DPPH was captured by the test antioxidant that releases hydrogen, thus forming the reduced DPPH [11]. DPPH violet color changes to yellow followed by a decrease in the wavelength of 
maximum absorbance $(515.6 \mathrm{~nm})$, it showed antioxidant activity which can be seen from the \% reduction.

Polyphenols that found of the G. mangostana L. leaves has a major role in prevention of various diseases. Polyphenols are a hundred times more effective than vitamin $\mathrm{C}$ and 25 times more effective than vitamin $\mathrm{E}$. This substance also serves to neutralize free radicals. Leaves of G. mangostana contains xanthon (mangostin, garsinon) flavonoids and tannins that serves as a precursor catch (scavenger) compounds of oxygen radicals (ROS). Flavonoids have antioxidant activity that serves as a binding element in the body of harmful metals. In some plant, phenolic compounds are potent antioxidants: flavonoids, tannins, and lignins are precursors of compounds acting on the arrest of ROS.

Mechanism of action from free radical scavenging is to reduce the free radicals by giving one or more electrons to free radicals to form a normal molecule. The ability of flavonoids as antioxidants are due to the catechol group on the B ring that acts as an electron donor. Oxygenation pattern in B ring is indicated by the ortho hydroxy group at position 3 and act 4 as antioxidants [10].

Free radical scavenging activity of juice, ethanol extract (EE) and d- $\alpha$ - tocopherol were shown in Table 2. It showed that there were positive correlation between concentration of samples and percentage of inhibition. $\mathrm{IC}_{50}$ value of juice was $19.372 \mu \mathrm{g} / \mathrm{ml}$ which was ten times less than ethanol extract $\left(\mathrm{IC}_{50} 1.965 \mu \mathrm{g} / \mathrm{ml}\right)$ and twenty six times less than $\mathrm{d}$ - $\alpha$-tocopherol ( $\mathrm{IC}_{50}$ $0.737 \mu \mathrm{g} / \mathrm{ml})$. Ethanol extract was three times less than d- $\alpha$-tocopherol (figure 1). However, $\mathrm{IC}_{50}$ of juice and ethanol extract exhibited greater value if it was compared with the $\mathrm{IC}_{50}$ of ethyl acetate and acetone extract of $G$. mangostana that was reported by Sulaiman et. al. [12] ( $\mathrm{IC}_{50} 30.01$ and $33.32 \mu \mathrm{g} / \mathrm{ml}$ ).

Table 2: $\mathrm{IC}_{50}$ Value of Juice, Ethanolic extract, and da-tocopherol

\begin{tabular}{|c|c|c|c|c|c|}
\hline Sample & $\begin{array}{l}\text { Concentration } \\
(\mathrm{ppm})\end{array}$ & $\begin{array}{l}\text { Precentage } \\
\text { of inhibition } \\
(\%)\end{array}$ & $\begin{array}{l}\text { Linier } \\
\text { regressior } \\
\text { equation }\end{array}$ & & $\begin{array}{l}\mathrm{IC}_{50} \\
(\mu \mathrm{g} / \mathrm{ml})\end{array}$ \\
\hline \multirow[t]{4}{*}{ Juice } & 100 & 30.906 & $\bar{Y}$ & $=$ & \multirow{4}{*}{3719.} \\
\hline & 200 & 36.730 & $0.958 . \mathrm{x}$ & + & \\
\hline & 400 & 34.466 & 31.560 & & \\
\hline & 800 & 38.511 & & & \\
\hline \multirow{4}{*}{$\begin{array}{c}\text { Ethan } \\
\text { olic extract }\end{array}$} & 100 & 414.239 & $\mathrm{y}$ & $=$ & \multirow[t]{4}{*}{1.9} \\
\hline & 200 & 538.834 & 5.74.x & + & \\
\hline & 400 & 601.982 & 38.4136 & & \\
\hline & 800 & 843.042 & & & \\
\hline$d-\alpha-$ & 20 & 22.006 & $\mathrm{y}$ & $=$ & \multirow[t]{5}{*}{0.7} \\
\hline \multirow[t]{4}{*}{ tocopherol } & 40 & 29.288 & $58.356 x$ & + & \\
\hline & 60 & 36.569 & 7.0456 & & \\
\hline & 80 & 54.854 & & & \\
\hline & 100 & 67.579 & & & \\
\hline
\end{tabular}

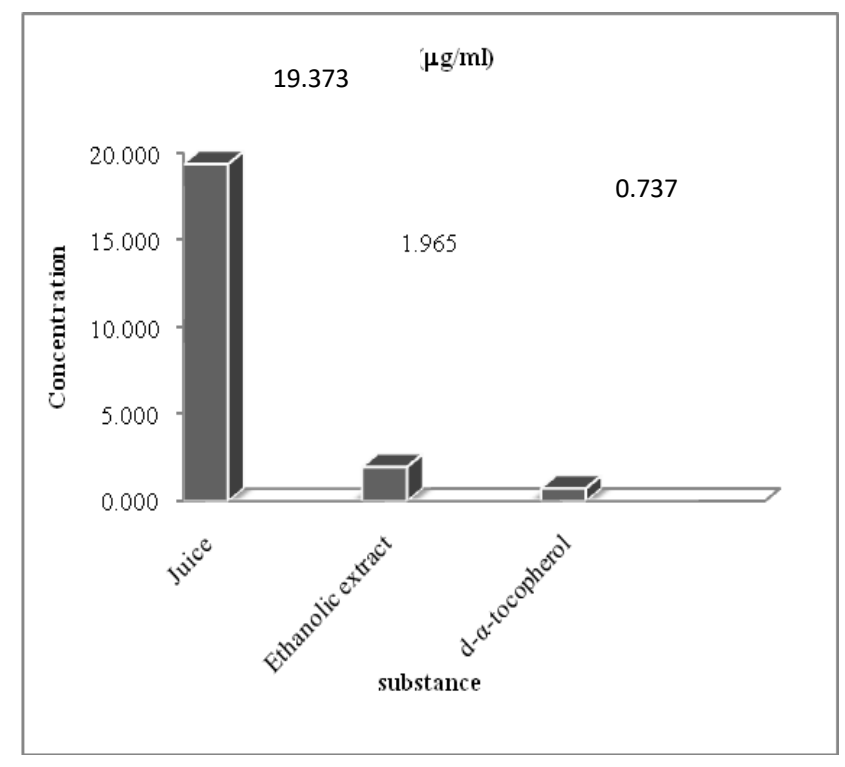

Figure 1. $\mathrm{IC}_{50}$ Value of Juice, Ethanolic extract of $G$. mangostana leaves, and $\mathrm{d}-\alpha$-tocopherol

Juice and ethanol extract contains various compounds from G. mangostana L leaves parts that might have synergistic effect to scavenge free radicals from DPPH. The major secondary metabolites of mangosteen have been found to be prenylated flavonoid xanthone derivatives [13]. Prenylated flavonoid xanthone which isolated from leaves of $G$. mangostana were 1,5,8Trihydroxy-3-methoxy-2-(3-methylbut-2-enyl)xanthone and 1,6-Dihydroxy-3-methoxy-2-(3-methyl-2-buthenyl)xanthone (Figure 1)(5).

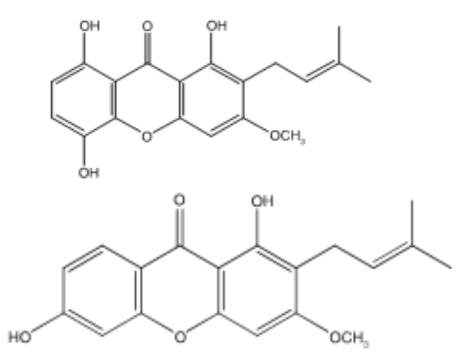

Figure 2. 1,5,8-Trihydroxy-3-methoxy-2-(3methylbut-2-enyl)xanthone and 1,6-Dihydroxy-3methoxy-2-(3-methyl-2-buthenyl)-xanthone (5)

Flavonoid could act as free radicals scavenger by the ability of ortho dihydroxy groups donating one or more electron to DPPH that will change the free radicals to be reduced (stable) form (DPP-hydrazine) with the transformation of purple color to yellow color [14].

Based on the result of anova test with significantly degree $95 \%$, it can be concluded that free radical scavenging activity between juice and ethanol extract were different with d- $\alpha$-tocopherol with DPPH $(1,1$ difenil-2-pikril hidrazil) as free radicals. 


\section{CONCLUSION}

Free radical scavenging activity from juice is ten times less than ethanolic extract from $G$. mangostana leaves with $\mathrm{IC}_{50}$ values for juice and ethanolic extract was 19.372 and $1.965 \mu \mathrm{g} / \mathrm{ml}$ with DPPH as free radicals and it needs further confirmation of compounds that is contained in juice and ethanolic extract.

\section{ACKNOWLEDGEMENT}

The researchers would like to thank Directorate General of Higher Education, Ministry of National Education Republic of Indonesia for the research funding.

\section{REFERENCES}

[1] Xin-Hong Wang and Jing-Tao Dai, "A comparative research on antioxidant activity of water and ethanol extracts of ten Chinese herbs," Journal of Medicinal Plants Research, 6(11), 2210-221, 2012.

[2] Kosem, N.., Han. Y.H., and Moongkarndi, P., "Antioxidant and Cytoprotective Activities of Methanolic Extract from Garcinia mangostana Hulls," Science Asia, 33, 2007.

[3] Dorly, et al., "Secretory Duct Structure and Phytochemistry Compounds of Yellow Latex in Mangosteen Fruit," Journal of Biosciences, 15(3), 99-104, 2008.

[4] Nilar, Leslie J and Harrison., "Xanthones from the heartwood of Garcinia mangostana," Research Report, Singapore: National University of Singapore, Department of Chemistry, 2002.

[5] Obolskiy, D., Pischel, I, Siriwatanametanon, N and Heinrich, M., "Garcinia mangostana L.: A Phytochemical and Pharmacological Review," Phytother. Res. 23, 1047-1065, 2009.
[6] Pedraza, et al., "Medicinal properties of mangosteen (Garcinia mangostana)," Research report, Mexico : Autonoma National University of Mexico, Departament of Biologi. 2008.

[7] Sukma, M., et al., "Antioxidant properties of squeezed mangosteen juice," Thai J. Pharm. Sci. 35. 176-18, 2011.

[8] Sunarni, T., "Flavonoid antioksidan penangkap radikal dari daun kepel (Stelechocarpus burahol (B1.)Hook f. \& Th.)," Majalah Farmasi Indonesia, 18(3), $111-116,2007$

[9] Jantan, I., et al., "Inhibitory Effects of the Extracts of Garcinia Species on Human Low-density Lipoprotein Peroxidation and Platelet Aggregation in Relation to Their Total Phenolic Contents," Journal of Medicinal Plants Research, 5 (13), 2699-2709, 2011.

[10] Diniatik and Suparman, "Uji Antioksidan Ekstrak Etanol Daun dan Kulit Batang Manggis (Garcinia mangostana L.).," Pharmaciana, 6(1), 21-30, 2016.

[11] Priya,V., et al. "Antimicrobial activity of Pericarp Extract of Garcinia mangostana L.," International Journal of Pharma Sciences and Research (IJPSR). 1(8), 278-281, 2010.

[12] Sulaiman, et al., "A Research of antioxidant Properties from Garcinia mangostana L. Pericarp Extract," Acta Sci. Pol., Technol. Aliment. 8(1), 23-34, 2009.

[13] Hyun-Ah Jung, Bao-Ning Su, William J.Keller, ¥Rajendra G.Mehta, And A.Douglas Kinghorn., "Antioxidant Xanthones from the Pericarp of Garcinia mangostana L (Mangosteen)," Journal of Agricultural and Food Chemistry, 54, 20772082, 2006.

[14] Molyneux, P., "The use of the stable free radical diphenylpicrylhydrazyl (DPPH) for estimating antioxidant activity," Songklanakarin Journal of Science and Echnology, 26, 211-219, 2004. 